\title{
A comprehensive study onGreen\& Sustainable Practices used by selected Hotels of New Delhi
}

Dr. Ayesha Siddiqui*, Principal,Sinhgad Institute of Hotel Management \& Catering Technology, Lonavala, Dist : Pune, Maharashtra , India, email:principal.sihmct@sinhgad.edu Gaurav Gomase**, Asst. Professor, Sinhgad Institute of Hotel Management \& Catering Technology, Lonavala, Dist : Pune, Maharashtra , India, email: gaurav.gomase.sihmct@sinhgad.edu

Contact No. 8208448898

\begin{abstract}
BACKGROUND:Hospitality\& Tourism industry is a major industry contributing to $10 \%$ of GDP of the country. wherein they have a significant economic, social and ecological impact on the nature. Today owing to Pandemic, this sector is badly hit due to closure of tourism operations and restricted movement of people across the country and globally. Tourism and hospitality definitelyadd to generation of waste, but if managed systematically the environment can be protected from damage. Today mankind is hit by virus and the reason is we have not respected the environment. Therefore, in recent years, Indian Government has taken strict measures and made mandatory guidelines for hotels in tourist spots to comply with all environment friendly practices like proper disposal of wet \& dry garbage, recycling of water, sewage treatment plants installation in premises, horticulture and minimal use of plastic etc.Five Star hotels were generally assumed as a place to enjoy vacation, using swimming pool and enjoying world cuisine but nowadays people have started asking for recycle paper, recycled linen, recycled amenities in room etc. With this changing trend, hotels need to adapt to new approach and start using green initiatives which give rise to green and eco-friendly hotels. This in turn would benefit mankind, environment and a better future will be passed on as legacy to coming generations. This paper therefore analyses the environment friendly practices of selected hotels of Delhi and the awareness among the staff.
\end{abstract}

Keywords - Green Hotels, Sustainability, Carbon footprints, Global climate change, Environment -friendly 


\section{INTRODUCTION}

Sustainable development and tourism are related as they are interdependent. Tourism is not a new term to this generation; it's being used since human civilization came into existence. Tourism sector showed the fast development in the country socially and economically bringing in more money and lot of investment opportunities in this industry. Hotels are the backbone of the hospitality industry though they bring in profit but at the cost of various problems for the environment. (Kasliwal,2017)

From the past decade, consumers have become aware of the deteriorating environment and have started implementing green initiatives. With the fast decline in the environment graph due to deforestation, pollution and carbon emission, people have started consuming ecofriendly goods and also making others aware about it. (Thakur, 2016)

In the late 70's the worldwide movement for environment and reducing carbon in environment gave birth to Eco Tourism. The development in green practises to make it more responsible form of tourism example Sustainable Tourism, Community Based Tourism, And Green Tourism has increased.Since 1980 Green Tourism has been a great demand by environment lovers to protect our mother earth and sustainable development for the coming generation to experience tourist places in stable state and to spread awareness which results in conservation and preservation of nature and culture, to keep up the history of civilisation.(Thakur,2016)

This change has rapidly increased the demand of green hotels which use eco- friendly practises within hotel. Now with this great demand, hotel's management need to plan and come up with greatservices which will not affect the purchasing power of the consumers and also give quality service without compromising on the comforts and services of the hotel. Research and development team has come up with many technologies which can be used in replace of current gadgets as well as use of paper in making products, reducing plastic waste, proper use of water and energy, using alternate energy and eco certification etc.to promote the concept of “Green Hotels” (Gautam,2015)

As stated by United Nation’s World Tourism Organisation, “ASustainable Tourismisthat meets thedemand of the customer, protect and improves it to save it for future generations to come. Sustainable means that can be maintained for a long time and helps in generating profits, helps 
in cost cutting besides protecting the environment of that region in which it is practised. It has been noticed that countries in which hospitality plays an important role in their economy development and generating profit have often missed the opportunity of going green. (Thakur, 2016). Very lately i.e., in late 1990’s sustainable tourism has gained importance.

In 1987 "Our Common Future” of the World Commission on Environment and Development also known asthe Brundtland Commission Report has given a red alert to the world. According to report various measures and techniques were made if followed we could see improvement by 2000. But, even after almost two decades later, there has not been a drastic change in society and the environmental condition didn’t seem to change. According to recent reports, climate on earth will reach all time high in next 12 years. (Gautam,2015)

The Brundtland Commission's report focuses upon the issues that present generation is not working to supply the needs for the coming generation. Such improvements need economic development in highly tourist activity, individual need to follow and adopt habits according to the environment issues and consumption of the resources. (Gautam,2015)

Soon the hoteliers have realized the potential decreases of energy supply in the future, as well as the rising prices of energy sources (Goldstein \&Primlani, 2012). In response to this summit in the year 2008, first sustainable and environmental friendly hotel was established, with all possible sustainable practices like a solar panel or wind power on roof, rain water harvesting that was used for water in toilets and plantation as well as giving food to needy once. (Fukey\&Issac,2014).

"Innovation hotel" is the concept of the InterContinental Hotel Group (IHG) to be the first hotel chain to use renewable and clean energy sources to be used in operations. (Pizman, 2008).

The Orchid had laid the foundation of this green revolution in the Indian hotel industry in the year 1997, by being certified as the first five star "Ecotel" in Asia. Hospitality Valuation Services, HVS International, New York, a global consulting and services organization which is also an ISO certified body issued them this certification. An "Ecotel" certification signifies that the hotel which is certified, to be environment friendly in all operations and implementation of practices to conserve water, alternative energy and managing solid waste materials.

In order to be recognized as an Ecotel, it is important that the hotel fulfils the criteria laid down with respect to energy efficiency, conservation of water, management of solid waste, making employees aware about sustainability \& building community awareness. The initial investment 
to build eco hotels is high however this cost will be covered in future by cost cutting initiatives and low operation charge.

\section{OBJECTIVES}

- To determine the environmental-friendly practices by hotels of New Delhi.

- To determine the staff awareness towards carbon footprints.

- To understand the importance of eco friendliness in hotel industry.

\section{METHODOLOGY}

The details of the environmentally friendly initiatives taken by the perspective hotels was taken by means of interview of the HR personnel of the organizations. Questionnaires was filled up by the employees working in the organizations to check the employee awareness level regarding the environmentally friendly Initiatives and practices taken up by their organization.This research is on the Implementation of Green Eco friendly, Sustainable practices implemented by the hotels of New Delhi.

Sampling Methods \& Data Collection:Three Hotels situated in New Delhi was taken, ITC MauryaSheraton,Welcom Hotel Dwarka and Radisson Blu Marina.15-20 employees each were randomly selected from various department of the hotel, personal interview was conducted with the Human Resource Personnel's. Convenient time and appointment were taken for the same, Websites, Articles, Previous Research, Magazines and Books were also referred.

Questionnairewere filled up by the employees, randomly selected from different departments of the hotels. Later data was statistically analysed to attain the results.

\section{LITERATURE REVIEW:}

\section{Sustainability Practices in India}

Indian Hotels have inspirations for becoming environmentally friendly, socially responsible and a conscious for the environment. Besides this government, legislations and financial advantages in long run has enhanced by upgrading hotel's base line infrastructure, thereby many smart hoteliers are working on savings to guests expenditures by reducing the rack rates of the rooms which in turn resulted in the increase of room occupancy. 
Going green is trendy nowadays in the hotel industry can be seen by the increased number of green hotels in India in last decade. ITC Windsor, ITC Maurya, The Orchid, Mumbai are theinitiators and yet more in pipeline. The Green Hotels have adopted policies and practices like reuse of linen and towel in guest rooms. Provision of low-flow showers and toilets, occupancy sensors to control lighting and air conditioner. India has a varied climate so there is a need of large amounts energy whether it is to keep guests warm during chilly winters like in Shimla, Darjeeling, Ooty or Manali or help guests keep cool in extremely hot climates such as in the case of Jaipur, Udaipur, Chennai, Ahmedabad or Hyderabad. Hotels and resorts have cut down on overheads generously by means of appropriate checking of energy requirements and ideal use of accessible assets. (Amandeep,2017)

Since generations people are interested in travelling. Nowadays the generations are interested in eco travelling. However, each generations value green travel. Baby boomers (born between19461964) and Generation X (born between1961-1981) are environmentally conscious (44\% of Baby Boomers and $42 \%$ of Generation X call themselves 'environmentalists'). At present the Baby boomers are active travellers whereas the Generation $\mathrm{X}$ has time and money to spend on travelling but are not travelling as often as the Baby Boomers. Hence the later becomes the important consumer groups for the hotel industry.

Millenials (born between1981-2001), the biggest generation, they are well informed and they value sustainable consumption. As sustainability is of prime importance to them $66 \%$ are willing to pay more for services by companies that are committed to creating a positive environmental impact.(Camilla Hallstrom, 2017)

The preferences of the consumers have changed ever since the coming of the companies like Couch surfing and AirBnB entered the markets.Digitalization and the changes in the mindset of this generation of millenials is "Leave It Better than You Found It" as one of their company's core values. The customer is preferring and is on the lookout for the hotels that are practising eco friendly operations. (Camilla Hallstrom, 2017)

With 54\% of world's population living in urban areas and the cities are growing rapidly. City dwellers are looking for sustainable travel experiences in nature and most importantly clean environment. (Harvard Business School) 
A survey in 2010 showed that 51\% business travellers are organizing their annual, quarterly or monthly meets as well as conferences in Eco-friendly and close to nature venues. Another instance wherein JW Marriott Denver says that $75 \%$ of the travellers are looking for hotels and venues with environment friendly alternatives. The business travellers are conscious travellers.

(Camilla Hallstrom, 2017)

Sun, natural resource is used into various innovations that can impact the visitor experience For example open lobbies near sea beach hotels wherein the natural light and natural air is preferred over the usage of electricity to light up or air-condition the lobby of the hotel. Special attention is being paid by the hotel housekeepers for the decorations and other front-of-house items that leave their influence on the customers and increase on their occupancy and ADR. (Camilla Hallstrom, 2017)

Young Hoteliers are embracing a sustainable business culture, that look past profitability and instead focus on benefits of the community. The young hoteliers want to be associated with the “Companies that make a difference”. (Camilla Hallstrom, 2017)

Sustainable practices, various resource conservation programs by the hoteliers are appreciated and supported by 33\%"Pre-Boomer" generation (people born before 1946), 87 percent of Baby Boomers (people born between 1946 and 1964), and 95 percent of Generation X (people born between 1965 and 1976) (Camilla Hallstrom, 2017)

Participation of the staff at the ground level is very important or else lack of staff awareness or initiative by them makes the whole effort of the management a failure. The executive director of J.D. Power \&Associates of Linda Hirneise, shared the same views about the initiatives taken by the corporate. (Camilla Hallstrom,2017)

With the efforts of the marketing team, sensitization of the customers is done by putting up various advertisements, tent cards in rooms on the various conservation practices by the hotels. As a result $82 \%$ percent of guests appreciated the idea of changing the linens and towels only by request,35 percent didn't mind in reusing and saving water in toilets and by showers. Hirneise(2017) . 
According to Watkins's (1994) study, the environment friendly initiatives taken by the hotels to influence the customers and also towards to sustainability are using of recycling bins, energy-efficient lighting, changing sheets on request and turning off lights in unoccupied guest rooms.

Kasim (2004) studied tourists to Penang Island, Malaysia and found that tourists are willing to accept rooms with water saving features, recycling bins, fire-safety features, and energy saving features but did not consider it the only reason of staying in a eco-hotel.

The study by Manaktola\&Jauhari (2007) conducted in NCR Delhi, India towards the consumer attitude and behaviour to the green practices in lodging industry. Only 15\% are willing of the customers are ready to pay for green hotels.

Millar and Baloglu, (2011) survey has identified the lists of green attributes which hotel guests would prefer in their room. Like energy saving bulbs, low flow toilets, key cards were accepted by majority of the guests.

Study conducted at Uttarakhand by V Nath et al (2012) on Green behaviours of Indian consumers showed that the consumer in tier III cities were well aware about the threats to the environment in near future but they lacked guidance for the optimum utilization of the resources and effective measures to be taken to prevent the harm caused to the environment.

\section{RESULTS AND DISCUSSION}

Details of the environmental-friendly practices taken up by Hotels of Delhi was arrived at, outreach of these practices to the customers and the awareness as well as the implementation by the staff was analysed and summarized. The hotels were visited to gather information about their Implementing Green- Ecofriendly, Sustainable practices.

Interview of the Human Resource Managers were taken at their convenient time. The Operational Heads and the various department supervisors were also interviewed. A questionnaire was filled up by the staff of food production, housekeeping, laundry, food and beverage service, personal department etc

\section{Details of the Green initiatives by The ITC Maurya Hotel:}


- It is the World's first hotel to be given the LEED Platinum Rating under the Existing Building category.

- In recognition of its endeavours to reduce carbon emissions UNFCC (United Nations Framework Convention on Climate Change) has claimed it to be the first hotel chain in the world to earn Carbon Credits under the carbon trading regime.

- Paraboloid Solar Concentrators is used for thermal need in the hotel (steam and hot water.) making it the first hotel chain to do so.

- To combat the waste water processing of about 800 Kilo Litres per day with potable water quality they have installed World's largest Membrane Bio Reactor for Ultra filtration of Waste Water.

- Approximately $25 \%$ of its energy demand is fulfilled through renewable source i.e., Wind and Solar.

\section{Details of the Green initiatives by The ITC Welcom Hotel Dwarka:}

- $100 \%$ of the rain that falls on the building is used by rain Harvesting Plants.

- Sewage treatment plantrecycles $100 \%$ of all the water used in the building including waste water to tertiary standards.

- External air-economizer draws $100 \%$ of the air from outside, inviting fresh air into the building during the low temperature outside.

- Low flow showers in the bathroom and a dual flushing system in the toilet. (1.5 litres discharged for liquid waste and 7 litres for solid waste.) is installed.

\section{Details of the Green initiatives by The Radisson Blu Marina:}

- Unique eco-friendly yet durable paper drinking straws are used that are $100 \%$ chemical free.

- Recycle bins in each room have be installed.

Hospitality is one of the key contributor in the Indian economy and growth, Sustainable practices need to be marketed to the foreigners, awareness programs should be implemented rigorously, recycling initiatives besides appropriate and judicious use of the resources will help in saving the energy resources.In India commercial buildings like hotels uses $1 / 3$ of the energy and water through cost cutting and efficient energy consumption equipments. 


\section{Result and Discussion}

A questionnaire was filled out by the employees to provide information about the secondary objective i.e. awareness level of the employees. The results are as follows:

\section{Taking up Initiative for eco Friendly Practices}

The Fig 1 shows that $\mathbf{1 0 0} \%$ of the respondents agree that Green eco friendly initiatives are taken by the hotels. They appreciate that such initiatives are needed in hospitality industry because they feel that they are giving back to the environment for what it has provided them by the means of Green Initiatives.

Tsai \& Tsai, (2008) study conducted in Taiwan on the impact of consumer environmental ethics on consumer behaviour in green hotels where they identified that the Taiwanese consumers are willing to support environmental protection and resource recycling policies of green hotels.

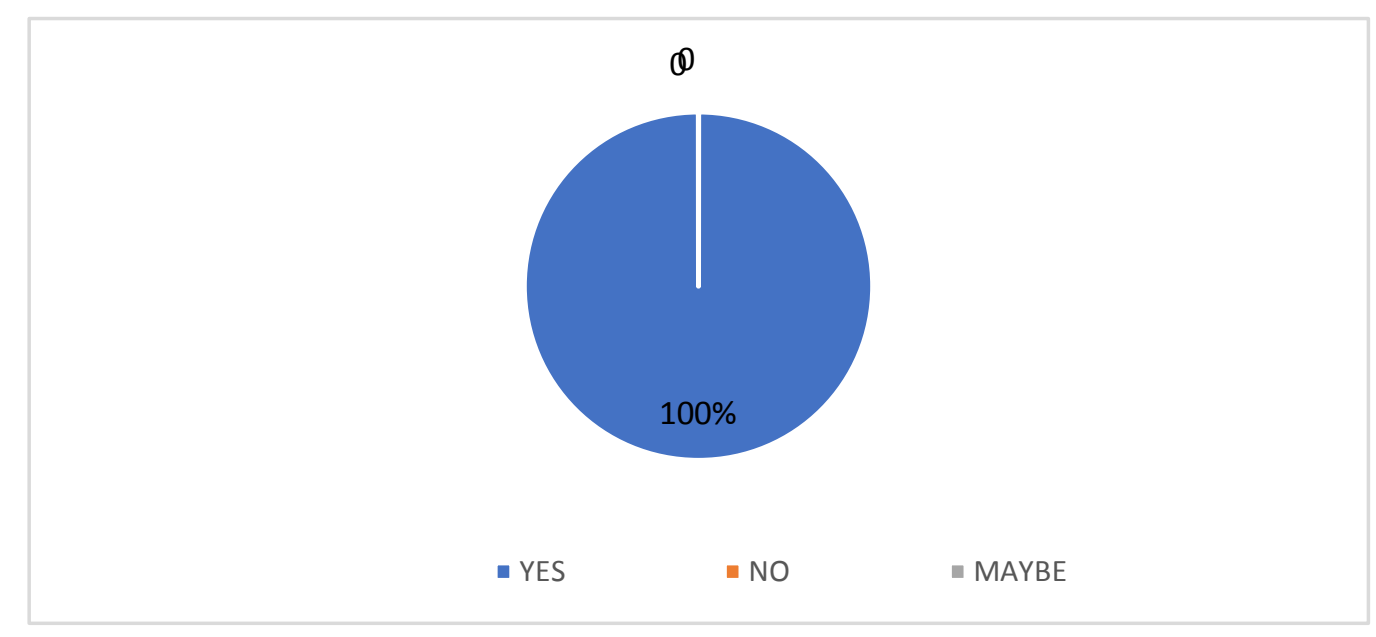

Fig 1: Green Initiatives taken by the Hotels 


\section{Awareness about Green Initiatives.}

The following Fig 2, depicts that $46 \%$ of the respondents were 'Very Well' aware about the Green Initiatives while the remaining $\mathbf{4 6 \%}$ of the respondents were just 'Aware' and $8 \%$ of the employees were somewhat aware about the presence of Green Initiatives in the organization. This infers that more participation is required from the employees by involving employees from all departments on a regular basis.

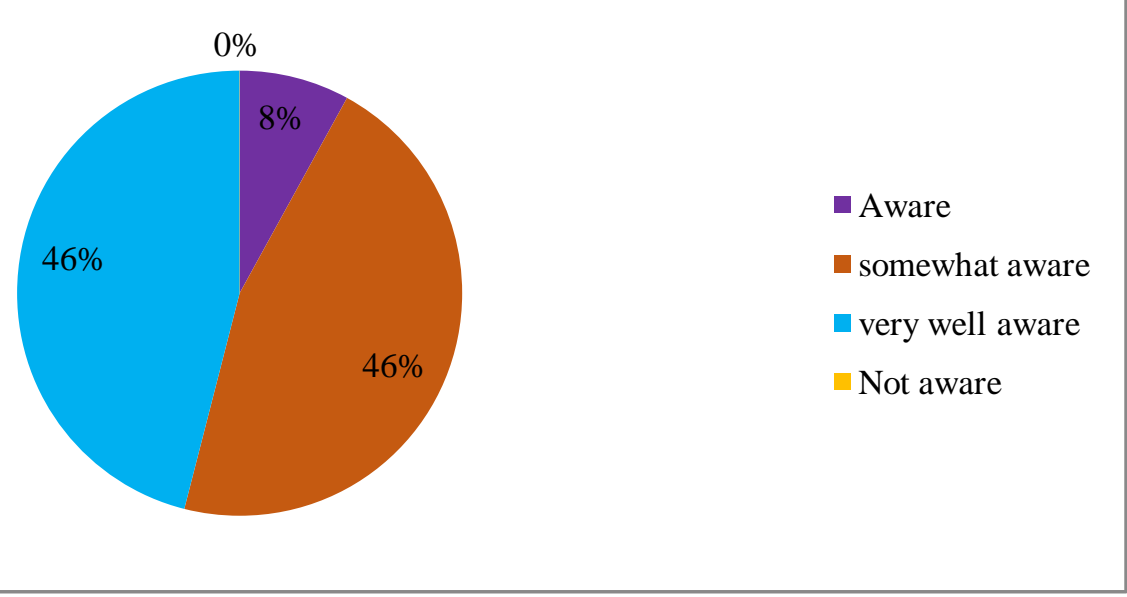

Fig. 2: Staff awareness level in the hotels

\section{Staff participation in the green initiative.}

The following Fig 3 depicts that $85 \%$ of the respondents were Agreeing and wanted to participate in the Green Initiatives while the remaining $15 \%$ of the respondents were not interested in doing so. Hotels should imply more awareness programs and should motivate the staff to actively participate in such initiative. 
Fig 3: Staff participation in the green initiatives.

\section{Reach of the Green Initiatives.}

The following Fig 4 depicts the reach of the Green Initiatives taken up by the organizations. It was found that the areas of maximum concern were Energy conservation, Quality Air, Water conservation, Solid waste management and environmental purchasing. This is because the respondents feel that the organization emphases more on energy conservation and works more towards preserving the environment by following green practices to contribute their part in conserving the environment.

There is a rise in the number of environmentalists Tourist and travellers as we observe that the phrase 'green hotel' is searched 2,900 times on Google in India and60,500 times across the globe in the 12-month average of user queries.(Amandeep,2017)

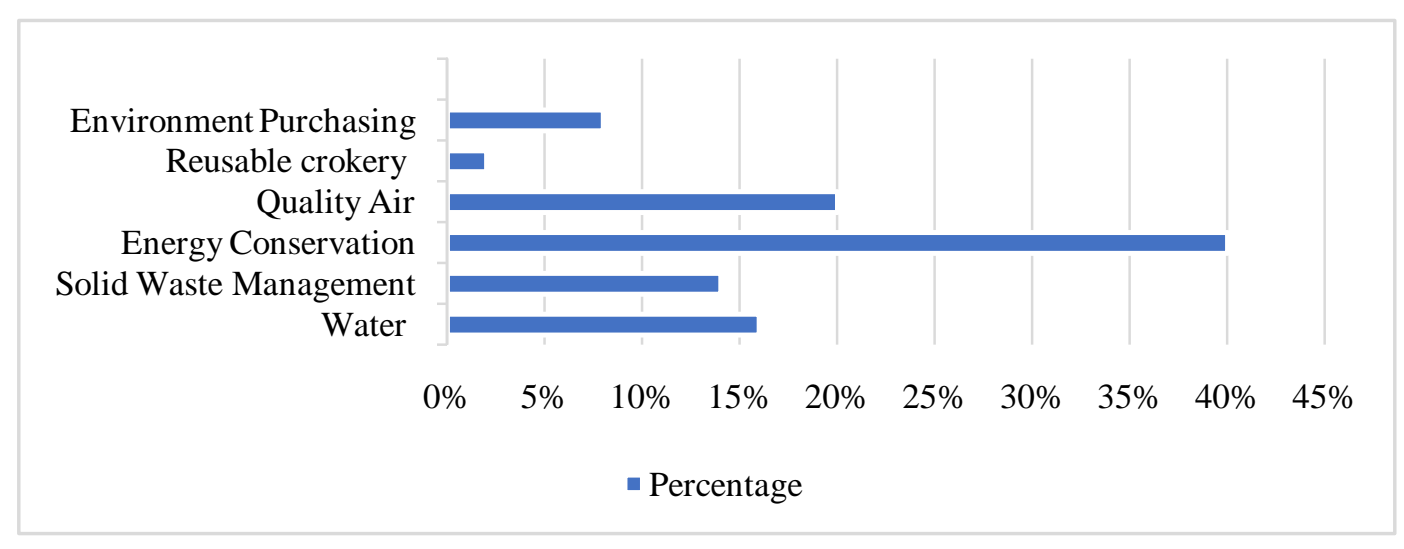

Fig 4: Green Initiatives taken up by the organizations.

\section{Responsible person for Green Initiative in the hotel}

The following Fig No.5 depicts the person or the team responsible for the Green Initiatives. It was found that primarily General Manager, Chief Executive Officer, Human Resource Manager, Public Relation teams take up the initiatives and directly coordinates the flow of Initiatives in the organization. 


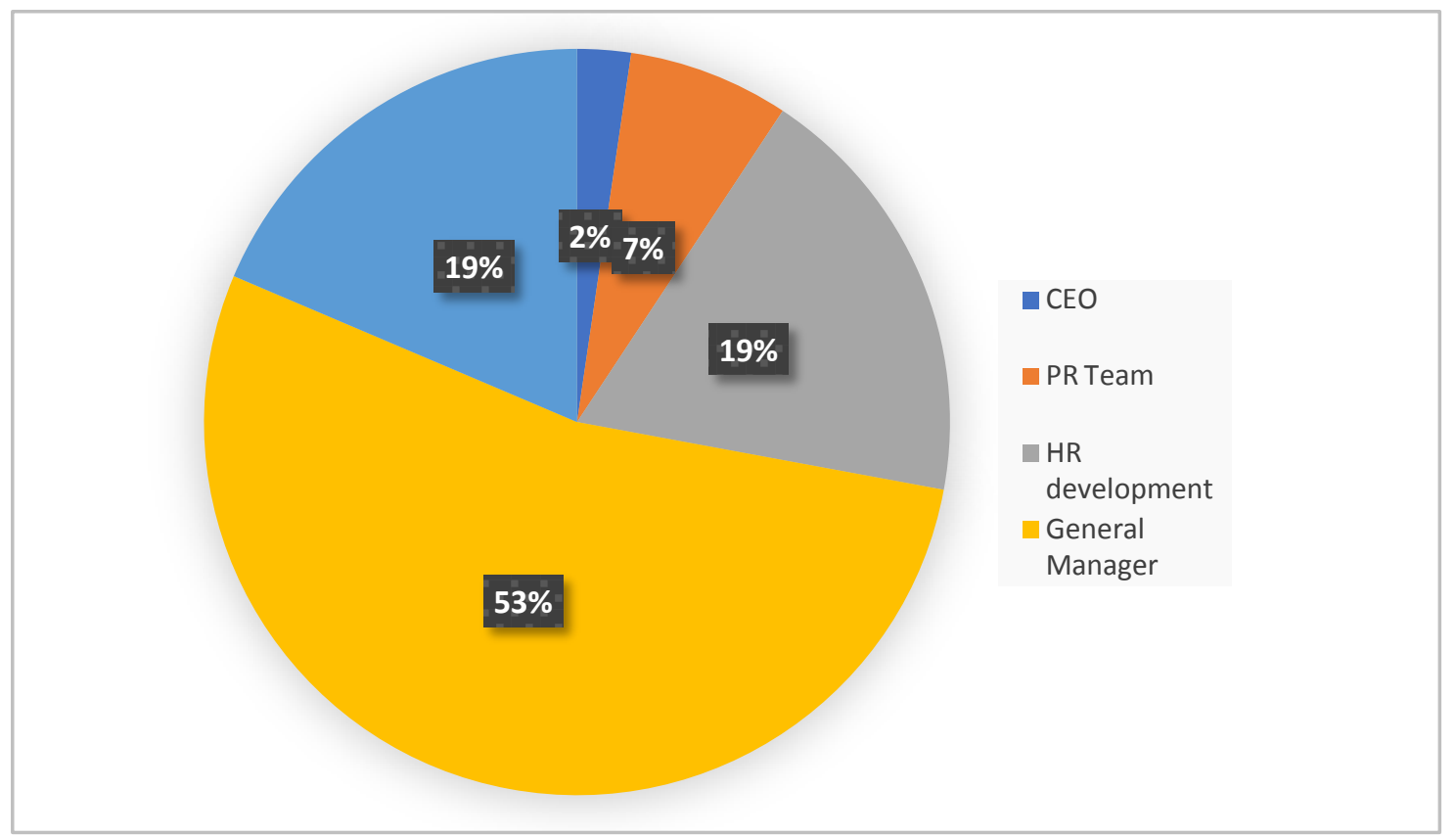

Fig 5 : Responsibility for implementation of Green Initiative.

\section{Annual Budget}

The given pie chart Fig 6 shows that in $78 \%$ of cases, Annual Budget for Green initiatives is 'Not fixed'. Also it shows that $16 \%$ organization spends less than $2 \%$ of their profits for their Green Initiatives. This is because the organizations feel that they should contribute to the society as much as they can but there are times when the business is not profitable to a certain level so amendments have to be made in terms of the funds being allocated for carrying out these Initiatives.

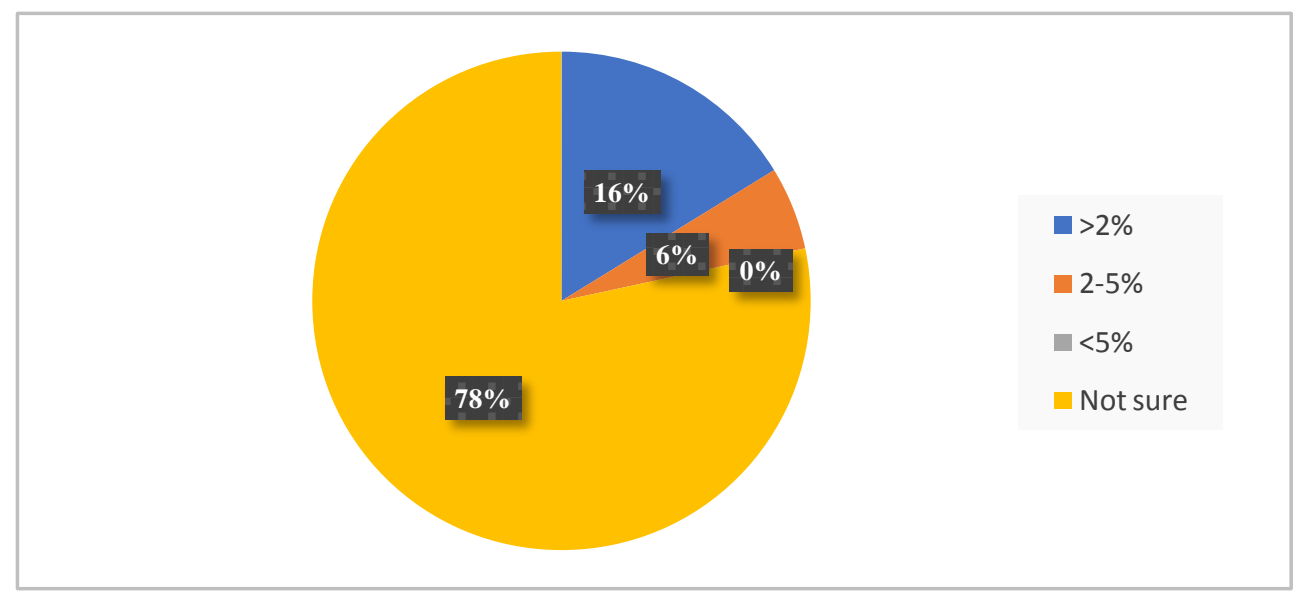


Fig 6 : Annual Budget allocation for green initiative

\section{Involvement of employee in Green initiative}

The following Fig 7 depicts that in $\mathbf{9 5 \%}$ of the cases the employees of the organisations are involved in Green activities and 5 \% responded no to it. So the hotels should organize various training classes for the new employees as well as updating and refreshing the staff such that they are able to cover up all the employees.

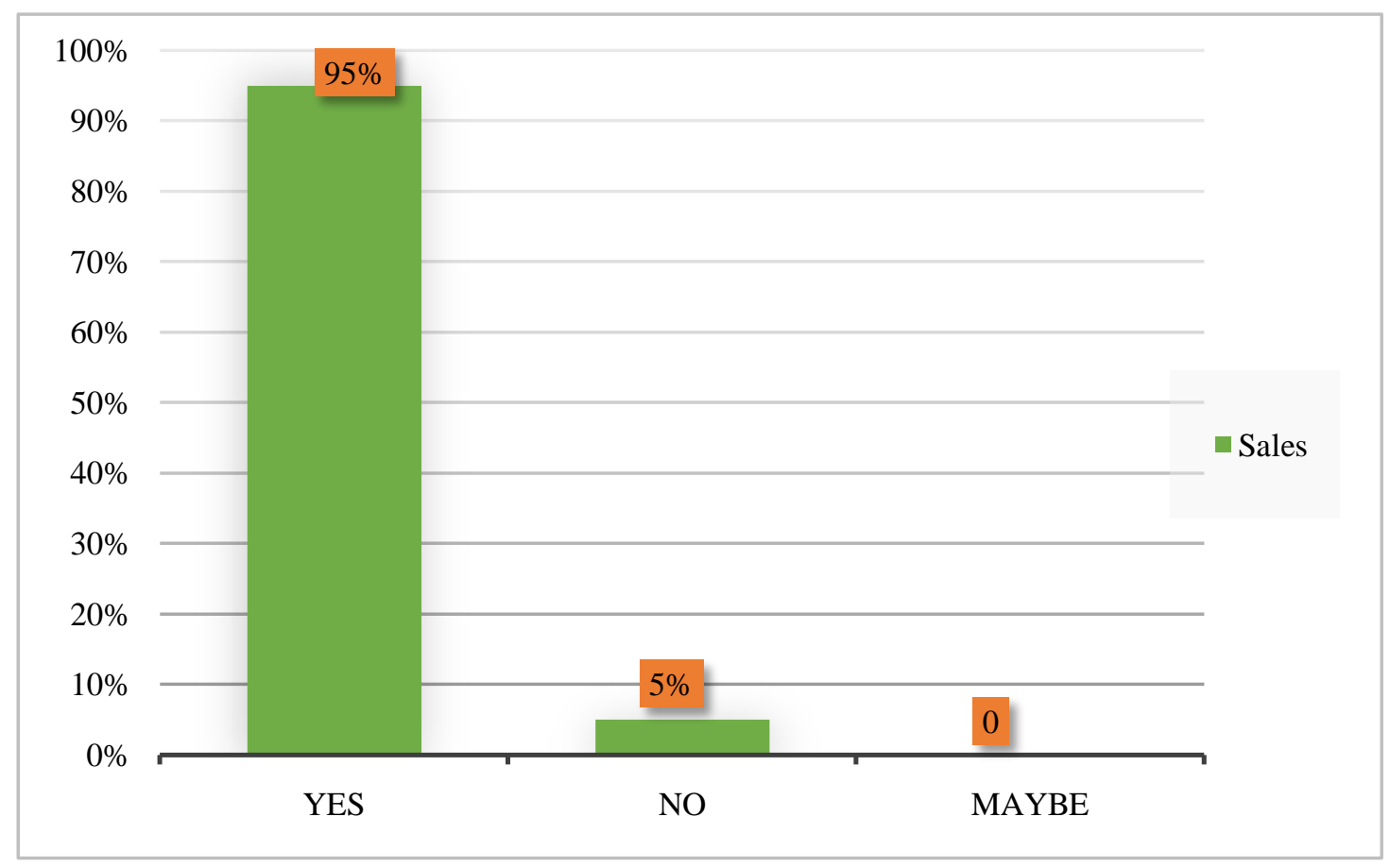

Fig 7: Involvement of Employee

\section{Frequency of Initiatives for employee}

The following Fig. 8 depicts that in $\mathbf{5 3 \%}$ of the cases, the organisations are involved in Green initiative awareness programmes that are done on a quarterly basis in a general aspect. This is because planning, organising and funding of these Initiatives take some time which makes the frequency of the initiatives at a quarterly basis.

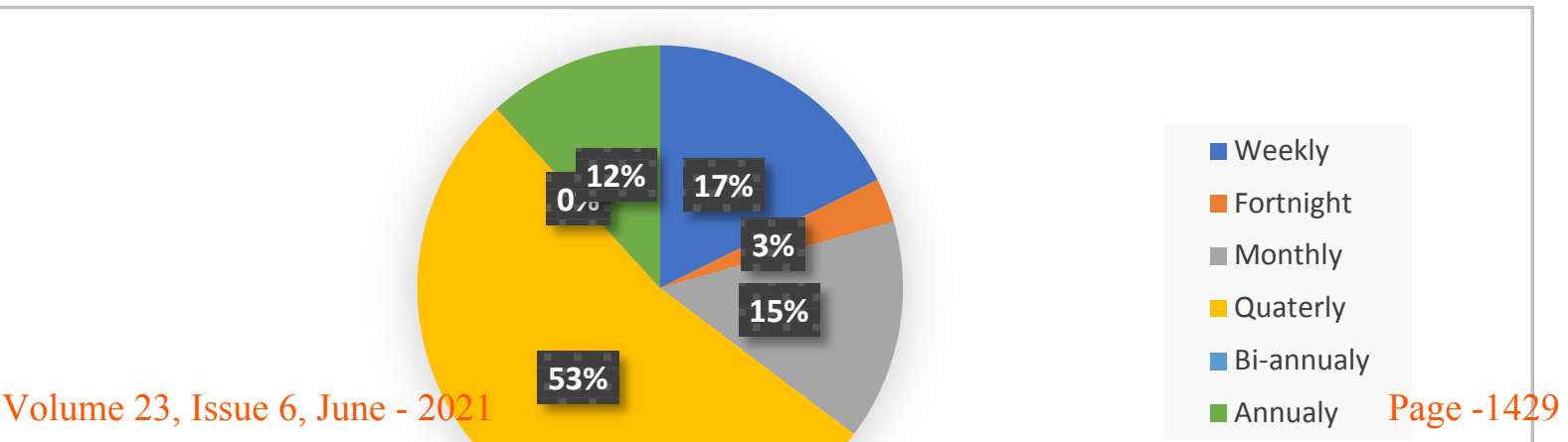


Fig 8 : Frequency of Initiative for employee

\section{Green Initiative bringing positive impact in society}

The fig. 9 given below shows that $86 \%$ of the respondents agree that Green Initiatives bring about a positive change in the society because this is the way of making people aware that organizations also contribute to the society and try to bring about a positive change in the society by the means of following the Eco Friendly- Green Initiatives.

Holiday Inn in Vancouver, Canada, was able to reduce $28 \%$ of its energy consumption by the usage of various modern energy management systems. Hospitality industry is making a conscious effort to optimize the consumption of non-renewable natural resources like water,coal,petrol etc. Hence they are contributing their share towards sustainable hospitality and in return of course this tends to lower costs for hotels. (Camilla Hallstrom, 2017)

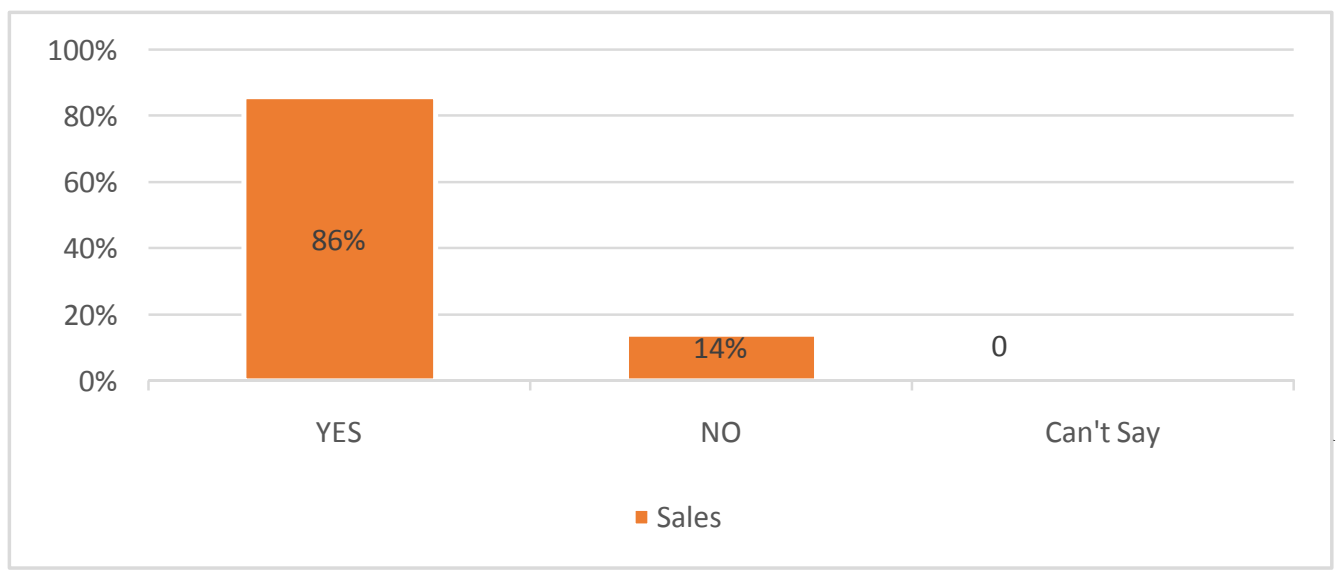

Fig 9 : Green Initiative bringing positive impact in society

\section{Guest are made aware of green initiative}

The following Fig 10shows $85 \%$ agrees that the guest are already aware of this activity and they comply by the step taken up by the Hotel. About 9\% disagrees to it and $6 \%$ say that they don't take any initiative to make the guest aware of the Green Initiatives. The lobby of 
the hotel may have standees advertising about the Eco friendly Green initiatives taken up by the hotels.

Laroche et al (2001) study has analysed demographically that married women travellers especially with kids are willing to pay for environmental friendly products, are more concerned towards environment and are likely to spend more to save it.

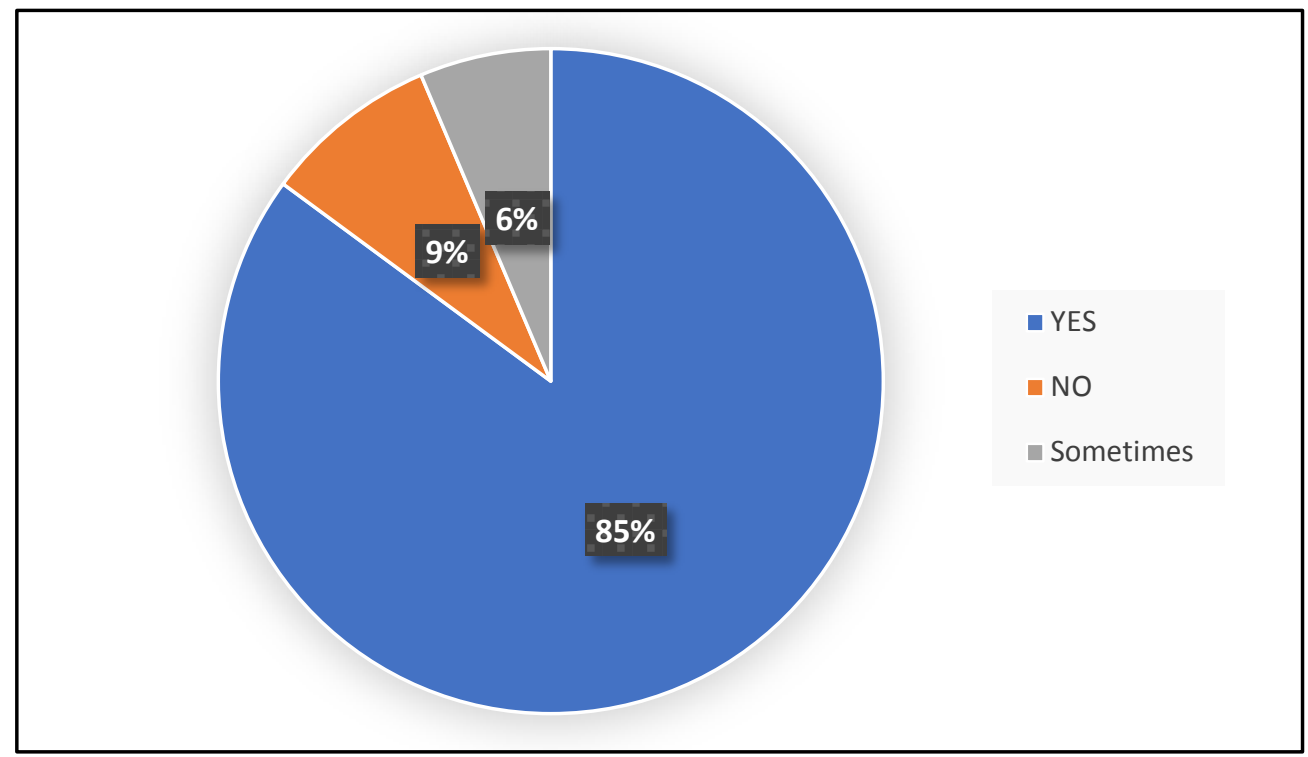

Fig 10 : Guest are made aware of green initiative

\section{Guest reaction to the Green Initiative of the hotel}

The Fig 11 shows that $\mathbf{8 6 \%}$ of the respondents agree that guest participate towards green Eco friendly initiatives taken by the hotels. They feel that such initiatives are needed in hospitality industry because they feel that they are giving back to the environment for what it has provided them by the means of Green Initiatives

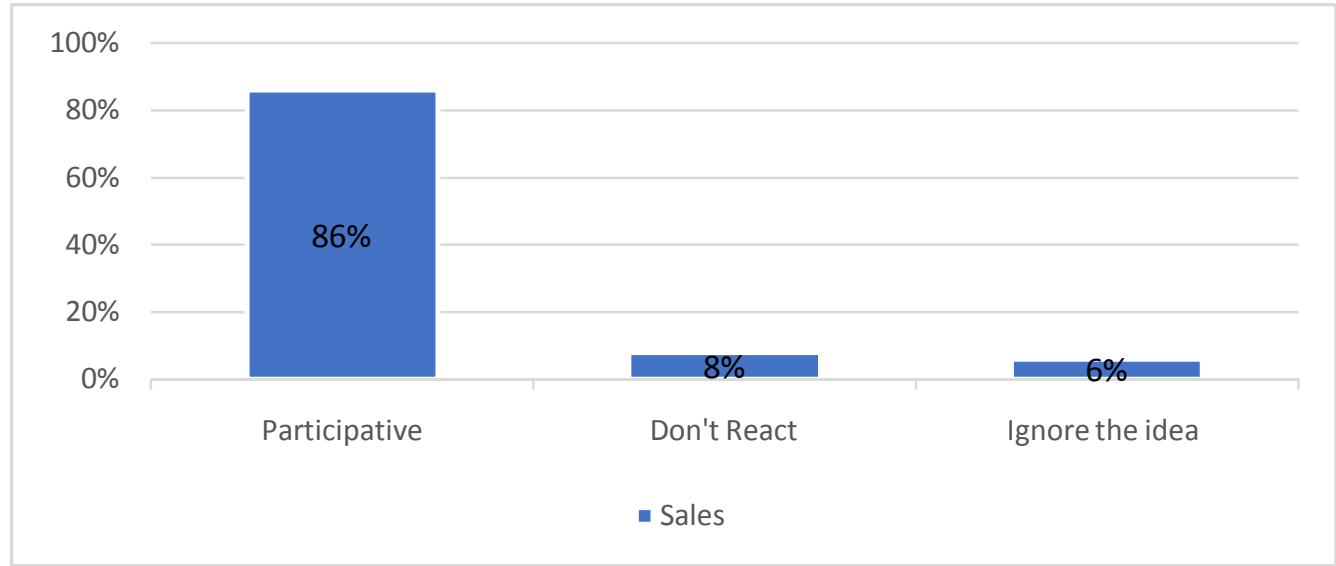


Fig 11 : Guest reaction to the Green Initiative of the hotel

\section{Summary}

Hotels have started taking Green Initiatives very positively and many have brought in changes in their standard operating procedures as well.More than $85 \%$ of the staff agreed and are keen in participating in green initiatives taken by the hotel. In present time all the new hotels plan well before staring the project and focuses on reducing natural resources which ultimately increase profits. Changes in the annual budgets are done according to the need of the hour.About $85 \%$ of the hotel staff marked that guests are involved in green initiatives.

General Manager of the hotel is responsible for making laws towards Green Initiatives. HR plays an important role too. Green initiatives followed by different hotels are Reusing Crockery, Reusing Water, Reusing Linen, enhancing the quality of air etc.It is interesting to know that $86 \%$ of the staff agreed that Green Initiative brings positive change in society.

Training programs are planned by the hotels for the staff awareness about the Green activities of the Hotel.It is beneficial for these hotels to get certain certifications in order to be environmentally compliant. A LEED-certified hotel provides benefits to the environment through energy efficient practices. Hotels that have these certifications and best practices can attract environmentally conscious travellers and stand out from other hotels.

\section{Conclusion}

With this research we were able to determine the different environmental-friendly practices adopted by hotels of New Delhi, the staff of the hotels were aware about the increase in carbon footprints and how the hotels are planning to contribute for a better and sustainable tomorrow for the generations to come.

As responsible citizens we can also contribute for sustainability and toward greener environment by small little efforts and changes in our daily habits. Some of these efforts are switch to LED tube lights in our houses, corridors etc. We should provide recycling bins both in guest rooms, public areas (eg. poolside) and in the back office to make recycling as easy as possible.Educate the people around us, students, children etc. turn off lights and turn down heaters or air conditioners in unoccupied rooms or while moving out of the unoccupied room. Should checkand respond to leaking faucets and toilets, taps etc. Open drapes to reduce the need for heat 
and ensuring that the sunlight as well as the fresh air should come in rooms, such that the freshens up, reduce the usage of electric lights and makes the room cool and fresh. We must check for power in unused equipments i.e., kitchen exhaust fans, switched on the TV plugs etc that have been left on.

Government should ensure that the rules for the sustainability are abided by the different corporate, Government office etc. Likebuying of office materials that are made of recycled material. All the offices should go paperless and proper inspections should be done to ensure the rules are properly followed.

Green travel is on the rise this year, the number of travellers who want eco-friendly travel options is projected to grow by $36 \%$ compared to 2016. At the same time, Hotel sustainability is on the rise thanks to changing customer preferences, demographics. Green travel benefits hotels in several different ways, from saved costs to gaining competitive advantages and risk management.

\section{REFERNCES}

- Agarwal, S. C.,(May 07, 2012 ), Eco-friendly hotels not only helps preserve the environment but is a cheaper alternative too - ET Bureau, Retrieved from https://economictimes.indiatimes.com/industry/services/hotels-/-restaurants/ecofriendly-hotels-not-only-helps-preserve-the-environment-but-is-a-cheaper-alternativetoo/articleshow/13009303.cms . Accessed on (27/9/2018)

- Amandeep (Feb 2017), Green Hotels and Sustainable Hotel Operations in India, international journal of management and social science research. Retrieved from https://www.researchgate.net/publication/313857970 Green Hotels and Sustainable H otel Operations in India. Accessed on (27/9/2018)

- Builder, Master (Nov, 2014 )The Indian Hotel Industry Thinking 'Green'- The Indian Hotel Industry Thinking 'Green', Retrieved from https://www.masterbuilder.co.in/indian-hotel-industry-thinking-green/ (25/12/18)

- Campbell, $\left(4^{\text {Th }}\right.$ quarter,2012), Case study :North Carolina Green Hotel Retrieved from https:://www.campbellsci.com/news-green-hotel,.(24/11/18) 
- Gautam, Prashant K.(2015) Sustainable Tourism Development- Guiding Principles for Planning and Management,The Nature and Scope of Sustainable Tourism, Eco Tourism retrieved from https://epgp.inflibnet.ac.in/ahl.php?csrno=1827(27/12/18)

- Hamid,Sheeba(2017) Sustainable Tourism Development- Guiding Principles for Planning and Management,Eco Tourism, retrieved from https://epgp.inflibnet.ac.in/ahl.php?csrno=1827.(27/12/18)

- Hallstrom Camilla (January 17th, 2017), Hotel Sustainability - Why Hotels Should Go Green , Miscellaneous, Retrieved from - https://www.hermesthemes.com/hotelsustainability-hotels-go-green/(24/12/18)

- Kasim, A. (2004.) Socio-environmentally responsible hotel business: Do tourists to Penang Island, Malaysia care? Journal of Hospitality and Leisure Marketing 11(4):528. $(22 / 11 / 18)$

- Kasliwal, Neeti( 2017) Study on Indian consumer attitude and choice of preference for green attributes of hotel industry. Retreived from IndianJournalofManagement paper2.(22/11/18)

- Laroche, M., Bergeron, J., \&Barbaro-Forleo, G. (2001). Targeting Consumers who are Willing to Pay More For Environmentally Friendly Products. Journal of consumer marketing,18(6), 503-520.(22/11/18)

- Lawson Erich_(Apr 4, 2018) , 6 ways sustainability is changing hotels , Hotel Management, Retrieved from - https://www.hotelmanagement.net/design/6-wayssustainability-changing-hotelsWilling to Pay More For Environmentally Friendly Products. Journal of consumer marketing,18(6), 503-520.(24/11/18)

- Manaktola, K., \&Jauhari, V. (2007). Exploring Consumer Attitude and Behaviour towards Green Practices in the Lodging Industry in India. International Journal of Contemporary Hospitality Management, 19(5), 364-377.(24/11/18)

- Millar, M., \&Baloglu, S. (2011). Hotel Guests’ Preferences For Green Guest Room Attributes. Cornell Hospitality Quarterly, 52(3), 302-311.(24/11/18)

- Millar, M., Mayer, K. J., \&Baloglu, S. (2012). Importance Of Green Hotel Attributes To Business And Leisure Travelers. Journal of Hospitality Marketing \& Management, 21(4), 395-413.(24/11/18) 
- Nath, V., Kumar, R., Agrawal, R., Gautam, A., \& Sharma, V. (2012). Green behaviors of Indian consumers. International Journal of Research in Management, Economics and Commerce, 2(11), 488-498.(23/11/18).

- Ogbeide, Godwin-Charles (2012) "Perception of Green Hotels in the 21st Century," Journal of Tourism Insights: Vol. 3: Iss. 1, Article 1.Retrieved from https://doi.org/10.9707/2328-0824.1032 and http://scholarworks.gvsu.edu/jti/vol3/iss1/1 (23/10/18)

- $\quad$ Siobhan O'Neill( Dec, 2013 ), 25 Years of Sustainability in India with ITC Hotels - Asia pacific , Retrieved from - http://www.greenhotelier.org/destinations/asia-pacific/25-years-of-sustainability-inindia-with-itc-hotels/.(22/11/18)

- Thakur, A. S.(2016) Sustainable Tourism Development- Guiding Principles for Planning and Management Eco Tourism retrieved from https://epgp.inflibnet.ac.in/ahl.php?csrno=1827.(22/11/18)

- Tsai, C. W., \& Tsai, C. P. (2008). Impacts of consumer environmental ethics on consumer behaviors in green hotels. Journal of Hospitality \& Leisure Marketing, 17(3-4), 284-313..(24/11/18)

- Watkins, E. (1994, April). Do guests want green hotels? Lodging Hospitality, 50(4), 7072.(24/11/18)

- Retrieved fromhttps://economictimes.indiatimes.com/industry/services/hotels-/restaurants/eco-friendly-hotels-not-only-helps-preserve-the-environment-but-is-acheaper-alternative-too/articleshow/13009303.cms.(23/11/18).

- Retrieved from https://epgp.inflibnet.ac.in/ahl.php?csrno=1827,e-Pg Pathshala under National Mission on education through ICT.(20/10/18). 